\title{
SYNTHESIS OF POTENT ANTAGONISTS FOR THE NATRIURETIC PEPTIDE CLEARANCE RECEPTOR (NPR-C)
}

\author{
ELAREF RATEMI* \\ Department of Chemical and Process Engineering Technology, Jubail Industrial College, P. O. Box No - 10099, Jubail 31961, Saudi Arabia. \\ Email: ratemi_e@jic.edu.sa
}

Received: 20 May 2017, Revised and Accepted: 14 September 2017

\section{ABSTRACT}

Objectives: The objective of this research was to design and prepare natriuretic peptide clearance receptor (NPR-C) antagonists with potential therapy for achondroplasia, an autosomal dominant disorder that interferes with the synthesis of the cartilage growth plate of long bones.

Methods: Peptides were synthesized by the standard solid-phase peptide synthesis (SPPS) protocol on Rink resin using the N-Fmoc/t-butyl protection methodology. Biological activity of NPR-C antagonists was assessed using ATDC5 cells.

Results: SPPS rapidly generated many crude compounds with purities exceeding $80 \%$. The synthesized ligands were further purified by liquid chromatography-mass spectrometry (LC-MS), and their identities were confirmed by MS and nuclear magnetic resonance. Ligands with nanomolar potencies were obtained.

Conclusion: Structure-activity relationship studies resulted in a good selection of stable, low nanomolar, and linear NPR-C antagonists.

Keywords: Natriuretic peptides, Clearance receptor, Achondroplasia, Osteocrin, Structure-activity relationship, Antagonists.

(C) 2017 The Authors. Published by Innovare Academic Sciences Pvt Ltd. This is an open access article under the CC BY license (http://creativecommons. org/licenses/by/4. 0/) DOI: http://dx.doi.org/10.22159/ajpcr.2017.v10i11.20146

\section{INTRODUCTION}

The natriuretic peptide (NP) family comprises four structurally related bioactive peptides. Atrial NP (ANP) (also known as ANF), brain NP (BNP), and C-type NP (CNP) are important regulators of mammalian physiology while dendroaspis NP (DNP) is found in snake venom. The mammalian peptides arise from the processing of precursors and consist of 28 (ANP), 31 (BNP), and 22 (CNP) residues. A conserved disulfide bridge creates a ring structure of 17 amino acid residues with a D-R-I conserved sequence (Fig. 1). Although many minor sites of expression have been detected, ANP is mainly synthesized by atrial cardiomyocytes, whereas BNP is secreted by ventricular cardiomyocytes under hypertensive conditions. CNP, initially found in brain, is most abundant in bone, kidney, and vasculature [1,2] .

The natriuretic peptides ANP, BNP, and CNP demonstrate a number of actions on the cardiovascular system including: Natriuresis, dieresis, and relaxation of vascular smooth muscle. They bind two classes of cell surface receptors: The guanylyl cyclase-linked A and B receptors (natriuretic peptide clearance receptor [NPR]-A and NPR-B) and the $\mathrm{C}$ receptor (NPR-C) which serves as a clearance receptor for the three peptides [2,3]. The recently cloned bone peptide osteocrin binds specifically to NPR-C and attenuates its inhibitory effect on natriuretic peptide signaling. Osteocrin was shown to augment CNP action in bone by blocking the NPR-C-mediated clearance [4]. CNP and osteocrin bind NPR-C by an almost identical sequence. Recently, the potential skeletal therapeutic benefit of the manipulation of the natriuretic system was demonstrated in the rescue of achondroplasia in a mouse model by CNP overexpression [5]. Achondroplasia, the most common form of shortlimbed dwarfism, is an autosomal dominant disorder that interferes with the synthesis of the cartilage growth plate of long bones. The role of the natriuretic system in the human skeleton has also been demonstrated by the severe dwarfism exhibited by patients carrying inactivating mutations in the guanylyl cyclase-B (GC-B) gene [6].
Osteocrin and CNP are not drug candidates due to their size and short half-life in circulation, and therefore, we envisioned that small molecules that potentiate endogenous CNP by antagonizing the CNP clearance receptor (NPR-C) would constitute a potential therapy for achondroplasia.

\section{METHODS}

\section{Reagents and solvents}

All commercially available reagents were purchased and used without further purification. Commercially available highly purified grade dimethylformamide (DMF, $>99.0 \%$ purity) and piperidine (redistilled) were purchased from Acros Organics, NJ, USA. Diisopropylethylamine (DIPEA), 0-(7-azabenzotriazole)-N,N,N,N'-tetramethyluroniumhexafluoro-phosphate (HATU), and all protected amino acids were purchased from ChemImpex International, Wood Dale, IL, USA. FmocIle-Rink resin, used for making the peptides, was purchased from NovaBiochem, (Merck), Germany. Readily available acylating aromatic building blocks, and all other reagents and solvents were purchased from Aldrich, USA.

\section{Reactions and purifications}

Solid-phase reactions were conducted according to the standard solidphase peptide synthesis (SPPS) protocols [7,8]and were monitored, for coupling completion, using the Kaiser Test. High-performance liquid chromatography (HPLC) was performed on a water semi-preparative HPLC system (Alliance 2695) equipped with PDA detector (2996). When using liquid chromatography-mass spectrometry (LC-MS), the Waters Alliance LC system was integrated with the ZQ Waters Mass detector system. The columns used were Vydac $\mathrm{C}_{18}(5 \mu \mathrm{m}, 4.6 \times 250 \mathrm{~mm})$, Vydac $\mathrm{C}_{8}(5 \mu \mathrm{m}, 4.6 \times 250 \mathrm{~mm})$, Vydac $\mathrm{C}_{19}(5 \mu \mathrm{m}, 10 \times 250 \mathrm{~mm})$, Phenomenex $\mathrm{C}_{18}(5 \mu \mathrm{m}, 21.2 \times 250 \mathrm{~mm})$, and Zorbax $\mathrm{C}_{8}(5 \mu \mathrm{m}, 21.2 \times 250 \mathrm{~mm})$. All HPLC solvents were filtered with a Millipore filtration system under vacuum before use. 
SPPS

SPPS was performed using glass or polypropylene (PP) tubes fitted with $20 \mu \mathrm{PE}$ frits and a capped leur bottoms (Aldrich/Supelco: product no. 57176). The reaction is shaken using an orbital shaker or simply stirred gently using a magnetic stirrer. All the peptide sequences were synthesized on the $N$-(9-Fluorenylmethoxycarbonyl)-L-isoleucine-Rink (Fmoc-Ile-Rink) resin (loading $0.62 \mathrm{mmol} / \mathrm{g}, 100-200 \mathrm{mesh}$ ) purchased from NovaBiochem, Germany. The sequential coupling of protected amino acids was performed using the HATU/DIPEA protocol. The diisopropylcarbodiimide/hydroxybenzotriazole (DIC/HOBt) protocol proved also successful [9].

\section{General procedure for Fmoc deprotection}

The Fmoc-protected peptidyl-resin was treated with $20 \%$ piperidine in DMF for 3 minutes. The resin was drained using a stream of Argon and the piperidine treatment was repeated twice, for 3 and 10 minutes. The resin was washed using the following standard washing cycle: DMF $(4 \times 4 \mathrm{ml})$, dichloromethane (DCM, $4 \times 4 \mathrm{ml})$, methanol $(\mathrm{MeOH}, 4 \times 4 \mathrm{ml})$, DCM $(2 \times 4 \mathrm{ml})$, and $\mathrm{MeOH}(2 \times 4 \mathrm{ml})$.

\section{Coupling of amino acids}

$0.05 \mathrm{mmol}$ of Fmoc-Ile-Rink resin was placed in the fritted PE tube and $2 \mathrm{ml}$ of DMF was added. The resin was then left for 10 minutes before being filtered. The Fmoc group was then deprotected using the Fmoc deprotection protocol mentioned above, and the resin was prepared for coupling to the next required amino acid residue as follows: The next Fmoc-amino acid (5 equivalents relative to the resin loading) and HATU (4.9 equivalents relative to the resin loading) were dissolved in DMF. The activation was then initiated by adding DIPEA (10 equivalents relative to the resin loading) to the amino acid solution. The resulting solution was then stirred and transferred immediately to the resin (preswelled in $1 \mathrm{ml}$ of DMF). The reaction tube was gently shaken or stirred for 90 minutes, and then, the coupling was terminated by filtering the solution from the resin. The resin was washed thoroughly as mentioned above. After drying the resin, the resin was analyzed by Kaiser Test to determine the completeness of the reaction and was then carried through the next cycle.

\section{Capping (final coupling) with aromatic tether}

The $N$-acetylation reaction on the Freidinger lactam (FL) was run for 2 hrs with 10 equivalents (relative to the resin loading) of the aromatic acid building block, 9.8 equivalents of HATU, and 20 equivalents of DIPEA.

\section{Cleavage of peptides}

Cleavage from the resin with simultaneous removal of side chains protecting groups was done by adding a solution of trifluoroacetic acid (TFA)/triisopropylsilane/ $\mathrm{H}_{2} \mathrm{O}(95: 2.5: 2.5)$ to the dry resin with stirring for $2 \mathrm{hrs}$. The resin was then removed by filtration and was washed twice with TFA. The combined filtrate was concentrated by removing most of the TFA and then was precipitated with cold ether. The precipitated peptide was isolated by centrifugation and the crude peptide was purified by LC-MS. Pure product $(>95 \%)$ containing fractions were pooled, concentrated, frozen, and lyophilized to yield the product as a white powder. Peptide structures were confirmed using HRMS and nuclear magnetic resonance (NMR). Peptides showed similar spectroscopic data for the peptide portion, including the FL moiety.

\section{Compound 1}

${ }^{1} \mathrm{H}$ NMR $\left(\mathrm{D}_{2} \mathrm{O}, 400 \mathrm{MHz}\right): \delta 9.36(\mathrm{~s}, 1 \mathrm{H}$, Quinoxaline ring), $8.25(\mathrm{~m}, 1 \mathrm{H}$, $\mathrm{Ar}-\mathrm{H}), 8.11(\mathrm{~m}, 1 \mathrm{H}, \mathrm{Ar}-\mathrm{H}), 7.92(\mathrm{~m}, 2 \mathrm{H}, \mathrm{Ar}-\mathrm{H}), 7.76(\mathrm{~d}, 2 \mathrm{H}, J=8.5 \mathrm{~Hz}$, Ar-H), 7.21 (d, 2H, J = 8.5 Hz, Ar-H), 4.72 (m, 2H, Asp-H $\alpha$ ), 4.54-4.34 (m, 3H, 2xlle-H $\alpha+$ D-Arg- $\mathrm{H} \alpha), 4.21$ (m, 1H, lactam- $\mathrm{H} \alpha), 3.40$ (s, 2H, $\mathrm{CH}_{2}-\mathrm{Ar}$ ), $3.21\left(\mathrm{~m}, 2 \mathrm{H}\right.$, lactam $\left.\mathrm{CH}_{2}-\mathrm{N}\right), 2.65$ (t, D-Arg CH$\left.{ }_{2}-\mathrm{N}\right), 2.55$ (dd, $2 \mathrm{H}$, Asp-H $\beta), 2.17-2.02\left(\mathrm{~m}, 4 \mathrm{H}\right.$, lactam $\mathrm{CH}_{2}+2 \mathrm{x}$ Ile-H $\left.\beta\right), 1.71-1.45(\mathrm{~m}, 8 \mathrm{H}$, D-Arg - $\left(\mathrm{CH}_{2}\right)_{2}+2 \mathrm{x}$ Ile-2H $\left.\gamma\right), 1.2(6 \mathrm{H}, 2 \mathrm{x}$ Ile-CH3 $\gamma$ ), and 0.95-0.81 (m, 6H, 2x Ile- $\mathrm{H} \delta$ ); high resolution (ESI-MS) calculated for $\mathrm{C}_{43} \mathrm{H}_{58} \mathrm{~N}_{12} \mathrm{O}_{9} 886.4450$, found 886.4445. Anal. Calcd for $\mathrm{C}_{43} \mathrm{H}_{58} \mathrm{~N}_{12} \mathrm{O}_{9}$ : C, 58.23; H, 6.59; and $\mathrm{N}$, 18.95. Found: C, 58.12; H, 6.68; and N, 18.86 .

\section{Compound 2}

${ }^{1} \mathrm{H}$ NMR (D $\mathrm{O}, 400 \mathrm{MHz}$ ): $\delta$ 7.26-7.09 (m, 5H, Ar ring) and 3.45 (s, 2H, $\mathrm{CH}_{2}$-Ar); high resolution (ESI-MS) calculated for $\mathrm{C}_{34} \mathrm{H}_{53} \mathrm{~N}_{9} \mathrm{O}_{8}$ 715.4017, found 715.4014 .

\section{Compound 3}

${ }^{1} \mathrm{H}$ NMR $\left(\mathrm{D}_{2} \mathrm{O}, 400 \mathrm{MHz}\right): \delta$ 7.49-7.43 $(\mathrm{m}+\mathrm{d}, 4 \mathrm{H}$, terminal $\mathrm{Ar}-\mathrm{H}), 7.39$ $(\mathrm{m}, 1 \mathrm{H}$, terminal Ar-H), 7.29-7.21 (dd, $4 \mathrm{H}, \mathrm{Ar}-\mathrm{H})$, and $3.36(\mathrm{~s}, 2 \mathrm{H}$, $\mathrm{CH}_{2}$-Ar); high resolution (ESI-MS) calculated for $\mathrm{C}_{40} \mathrm{H}_{57} \mathrm{~N}_{9} \mathrm{O}_{8}$ 791.4330, found 791.4319 .

\section{Compound 4}

${ }^{1} \mathrm{H}$ NMR ( $\mathrm{D}_{2} \mathrm{O}, 400 \mathrm{MHz}$ ): 9.56 (s, $1 \mathrm{H}$, Pyrazine ring), 8.92 (d, $1 \mathrm{H}$, Pyrazine ring), 8.71 (d, 1H, Pyrazine ring), 7.46 (dd, 2H, Ar-H), 7.19 (dd, $2 \mathrm{H}, \mathrm{Ar}-\mathrm{H})$, and $3.36\left(\mathrm{~s}, 2 \mathrm{H}, \mathrm{CH}_{2}-\mathrm{Ar}\right.$ ); high resolution (ESI-MS) calculated for $\mathrm{C}_{39} \mathrm{H}_{56} \mathrm{~N}_{12} \mathrm{O}_{9} 836.4293$, found 836.4288.

\section{Compound 5}

${ }^{1} \mathrm{H}$ NMR $\left(\mathrm{D}_{2} \mathrm{O}+\right.$ few drops of $\left.\mathrm{CD}_{3} \mathrm{OD}, 400 \mathrm{MHz}\right): 8.09$ (m, $\left.1 \mathrm{H}, \mathrm{Ar}-\mathrm{H}\right)$, 7.75-7.58 (m, 3H, Ar-H), 7.41 (dt, 2H, Ar-H), 7.32 (dt, 1H, Ar-H), and 3.94 (s, 2H, Gly-CH $)$; (ESI- MS)846.7 $\left(\mathrm{MNa}^{+}\right)$.

\section{Compound 6}

${ }^{1} \mathrm{H}$ NMR (D $\left.\mathrm{D}, 400 \mathrm{MHz}\right): 7.49$ (br d, 3H, Indol-H + Ar-H), 7.41 (br s, $1 \mathrm{H}$, Indol-H), 7.21 (d, 1H, Indol-H), 7.18 (d, 2H, Ar-H), 6.9 (dd, 1H, Indol-H), 3.81 (s, $3 \mathrm{H}, \mathrm{CH}_{3} \mathrm{O}$ ), and 3.40 (s, $2 \mathrm{H}, \mathrm{CH}_{2}$-Ar); high resolution (ESI-MS) calculated for $\mathrm{C}_{44} \mathrm{H}_{61} \mathrm{~N}_{11} \mathrm{O}_{10} 903.4603$, found 903.4598 .

\section{Compound 7}

${ }^{1} \mathrm{H}$ NMR $\left(\mathrm{D}_{2} \mathrm{O}, 400 \mathrm{MHz}\right): 7.86(\mathrm{dt}, 1 \mathrm{H}$, Benzofuran-H), 7.61 (dd, $1 \mathrm{H}$, Benzofuran-H), 7.56 (m, 1H, Benzofuran-H), 7.50 (d, 2H, Ar-H), 7.39-7.26 (m, 2H, Benzofuran- $\mathrm{H}), 7.21$ (d, 2H, Ar-H), and 3.39 (s, 2H, $\left.\mathrm{CH}_{2}-\mathrm{Ar}\right)$; high resolution (ESI-MS) calculated for $\mathrm{C}_{43} \mathrm{H}_{58} \mathrm{~N}_{10} \mathrm{O}_{10} 874.4337$, found 874.4334.

\section{Compound 8}

${ }^{1} \mathrm{H}$ NMR (D $\left.\mathrm{O}, 400 \mathrm{MHz}\right): 7.56$ (d, 2H, Ar-H), 7.31 (d, 1H, Furan-H), 7.11 (d, $1 \mathrm{H}$, Furan-H), 7.01 (d, $2 \mathrm{H}, \mathrm{Ar}-\mathrm{H})$, and 3.80 (s, $3 \mathrm{H}, \mathrm{CH}_{3} \mathrm{O}$ ); high resolution (ESI-MS) calculated for $\mathrm{C}_{38} \mathrm{H}_{55} \mathrm{~N}_{9} \mathrm{O}_{10} 797.4072$, found 797.4049.

\section{Compound 9}

${ }^{1} \mathrm{H}$ NMR (D $2,400 \mathrm{MHz}$ ): 7.55 (d, 2H, Ar-H), 7.32 (d, 1H, Furan-H), 7.11 (d, $1 \mathrm{H}$, Furan-H), $7.00(\mathrm{~d}, 2 \mathrm{H}, \mathrm{Ar}-\mathrm{H}), 3.84\left(\mathrm{~s}, 3 \mathrm{H}, \mathrm{CH}_{3} \mathrm{O}\right)$, and $3.85(\mathrm{~s}, 2 \mathrm{H}$, Gly- $\left.\mathrm{CH}_{2}\right)$; (ESI-MS)855.9 $\left(\mathrm{MH}^{+}\right)$.

\section{Compound 10}

${ }^{1} \mathrm{H}$ NMR ( $\left.\mathrm{D}_{2} \mathrm{O}, 400 \mathrm{MHz}\right): 7.58$ (d, 1H, Ar-H), 7.51 (d, 2H, Ar-H), 7.41 (dd, $1 \mathrm{H}, \mathrm{Ar}-\mathrm{H}), 7.21(\mathrm{~d}, 2 \mathrm{H}, \mathrm{Ar}-\mathrm{H}), 7.16(\mathrm{~d}, 1 \mathrm{H}, \mathrm{Ar}-\mathrm{H}), 5.95$ (s, 2H, OCH $\mathrm{O}$ ), and 3.39 (s, $2 \mathrm{H}, \mathrm{CH}_{2}-\mathrm{Ar}$ ); high resolution (ESI-MS) calculated for $\mathrm{C}_{42} \mathrm{H}_{58} \mathrm{~N}_{10} \mathrm{O}_{11}$ 878.4287, found 878.4283.

\section{Compound 11}

${ }^{1} \mathrm{H}$ NMR (D $\left.2,400 \mathrm{MHz}\right): 8.75$ (dd, $1 \mathrm{H}$, Naphthyl-H), 8.39 (dd, $1 \mathrm{H}$, Naphthyl-H), 8.29 (dd, 1H, Naphthyl-H), 8.12-7.91 (m, 2H, Naphthyl-H), 7.91 (m, 2H, Naphthyl-H), 7.31 (d, 2H, Ar-H), 6.99 (d, 2H, Ar-H), and $3.36\left(\mathrm{~s}, 2 \mathrm{H}, \mathrm{CH}_{2}-\mathrm{Ar}\right) ;(\mathrm{ESI}-\mathrm{MS}) 921.7\left(\mathrm{MH}^{+}\right)$.

\section{Compound 12}

${ }^{1} \mathrm{H}$ NMR (D $\left.0,400 \mathrm{MHz}\right): 8.34$ (m, 1H, Naphthyl-H), 8.04 (dd, $1 \mathrm{H}$, Naphthyl-H), 7.86 (dd, 1H, Naphthyl-H), 7.76 (dd, 1H, Naphthyl-H), 7.48 (d, 2H, Ar-H), 7.31 (m, 1H, Naphthyl -H), 7.21-7.12 (m+dd, 3H, Naphthyl $+\mathrm{Ar}-\mathrm{H})$, and $3.38\left(\mathrm{~s}, 2 \mathrm{H}, \mathrm{CH}_{2}-\mathrm{Ar}\right)$; high resolution (ESI-MS) calculated for $\mathrm{C}_{45} \mathrm{H}_{60} \mathrm{~N}_{10} \mathrm{O}_{10} 900.4494$, found 900.4487 .

\section{Compound 13}

${ }^{1} \mathrm{H}$ NMR $\left(\mathrm{D}_{2} \mathrm{O}, 400 \mathrm{MHz}\right): 8.84(\mathrm{~m}, 1 \mathrm{H}$, Quinoline- $\mathrm{H}), 8.44(\mathrm{~m}, 1 \mathrm{H}$, Quinoline-H), 8.17-7.88 (m, 2H, Ar-H), $7.73(\mathrm{dt}, 1 \mathrm{H}, \mathrm{Ar}-\mathrm{H}), 7.52(\mathrm{dt}, 1 \mathrm{H}$, Ar-H), 3.21-3.04 (m, 4H, Pip ring), 2.31 (m, 1H, Pip ring), and 1.61-1.42 (m, 4H, Pip ring); (ESI- MS)864.9 $\left(\mathrm{MH}^{+}\right)$. 


\section{Compound 14}

${ }^{1} \mathrm{H}$ NMR (D $\left.0,400 \mathrm{MHz}\right): 8.82(\mathrm{~m}, 1 \mathrm{H}$, Quinoline-H), $8.43(\mathrm{~m}, 1 \mathrm{H}$, Quinoline-H), 8.15-7.84 (m, 2H, Ar-H), $7.71(\mathrm{dt}, 1 \mathrm{H}, \mathrm{Ar}-\mathrm{H}), 7.52$ (dt,

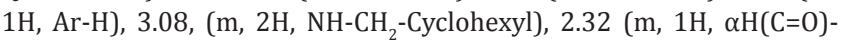
Cyclohexyl), 2.01 (m, 1H, Cyclohexyl ring), 1.78-1.55 (m, 4H, Cyclohexyl ring), and 1.38-1.21 (m, 4H, Cyclohexyl ring); high resolution (ESI-MS) calculated for $\mathrm{C}_{44} \mathrm{H}_{65} \mathrm{~N}_{11} \mathrm{O}_{9} 891.4967$, found 891.4961.

\section{Compound 15}

${ }^{1} \mathrm{H}$ NMR (D $\left.0,400 \mathrm{MHz}\right): 8.82(\mathrm{~m}, 1 \mathrm{H}$, Quinoline-H), $8.44(\mathrm{~m}, 1 \mathrm{H}$, Quinoline-H), 8.15-7.84 (m, 2H, Ar-H), 7.72 (dt, 1H, Ar-H), 7.50 (dt, 1H, $\mathrm{Ar}-\mathrm{H}), 3.01\left(\mathrm{t}, 2 \mathrm{H}\right.$, Hexyl chain- $\left.\mathrm{CH}_{2}-\mathrm{NH}\right)$, and chemical shifts of Hexyl chain (C2-C5) are overlapping with Ile and D-Arg side chains; high resolution (ESI-MS) calculated for $\mathrm{C}_{42} \mathrm{H}_{63} \mathrm{~N}_{11} \mathrm{O}_{9} 865.4810$, found 865.4798.

\section{Compound 16}

${ }^{1} \mathrm{H}$ NMR (D $0,400 \mathrm{MHz}$ ): 8.19 (d, 1H, Quinoline-H), 8.12 (dd, 1H, Quinoline-H), $7.83(\mathrm{~m}, 1 \mathrm{H}, \mathrm{Ar}-\mathrm{H}), 7.63$ (dd, 1H, Ar-H), 7.55 (m, 1H, $\mathrm{Ar}-\mathrm{H}$ ), 7.27 (dt, 1H, Ar-H), 2.51-2.55 (2 overlapping t, 4H, Succinimide), and $3.95\left(\mathrm{~s}, 2 \mathrm{H}, \mathrm{Gly}-\mathrm{CH}_{2}\right)$; high resolution (ESI-MS) calculated for $\mathrm{C}_{41} \mathrm{H}_{60} \mathrm{~N}_{12} \mathrm{O}_{10} 880.4555$, found 880.4551.

\section{Compound 17}

${ }^{1} \mathrm{H}$ NMR (D O, $\left.400 \mathrm{MHz}\right): 8.01(\mathrm{~m}, 1 \mathrm{H}$, Benzothiophene-H), 7.55-7.48 (d overlapping $\mathrm{m}, 3 \mathrm{H}$, Benzothiophene- $\mathrm{H}+\mathrm{Ar}-\mathrm{H}$ ), 7.26-7.19 (d overlapping $\mathrm{m}, 3 \mathrm{H}$, Benzothiophene-H + $\mathrm{Ar}-\mathrm{H}$ ), and 3.39 (s, 2H, $\mathrm{CH}_{2}-\mathrm{Ar}$ ); (ESI- MS) 943.4 $\left(\mathrm{MH}^{+}\right)$.

\section{Cellular assay}

ATDC5 cells [10]expressing endogenous CNP clearance receptor at the cell surface were used. Briefly, the $\mathrm{IC}_{50}$ of the synthesized peptides was determined in a competition assay using ${ }^{125}$ I-CNP as the tracer. ATDC5 cells were seeded in 24-well plates for 3 days and then were incubated in ${ }^{125} \mathrm{I}-\mathrm{CNP}$ and varying concentrations of cold ligands for 90 minutes at $4^{\circ} \mathrm{C}$.

\section{RESULTS AND DISCUSSION}

Recently, the bone peptide osteocrin was cloned and it was demonstrated that it specifically binds NPR-C with low nanomolar affinity and potentiates CNP action on cyclic guanosine monophosphate. Osteocrin and CNP are not drug candidates due to their short half-life in circulation, and thus, we looked at smaller molecules that are more stable and can augment CNP action in bone by blocking the NPR-Cmediated clearance. Small peptides were synthesized on Rink resin using the Fmoc SPPS strategy. The FL building block was synthesized using the literature procedure $[11,12]$. The subsequent $N$-acylation with the appropriate aromatic acid (aromatic tether) was done on resin. Using the same coupling protocol as for the amino acid sequence, it was found that the coupling was never complete. The $\mathrm{N}$-acetylation reaction on the FL moiety gave the best results when it was run for $2 \mathrm{hrs}$ with 10 equivalents (relative to the resin loading) of the aromatic acid building block, 9.8 equivalents of HATU, and 20 equivalents of DIPEA.

The synthesized peptides were cleaved from the solid support and were purified using LC-MS before biological testing. Our SPPS of compound 1, a known NPR-C antagonist [13], is presented below (Fig. 2) and the same synthetic protocol was adopted throughout the preparation of all final compounds.

Initially, we synthesized and tested compound 1 for a confirmatory study of its NPR-C antagonistic activity which was determined to be $5 \mathrm{nM}$. Furthermore, we tested the stability of this compound for further optimization studies. Compound 1 showed no degradation after $2 \mathrm{hrs}$ (at $4^{\circ} \mathrm{C}$ or $37^{\circ} \mathrm{C}$ ) during an in vitro stability study. However, the in vivo half-life was $<10$ minutes which prompted us to undertake a structureactivity relationship (SAR) study on this compound in search for molecules with better PK profiles. This paper reports on the influence of the aromatic tether on the biological activity. Table 1 summarizes a representative SAR study on the effect of varying the structure of the aromatic tether.

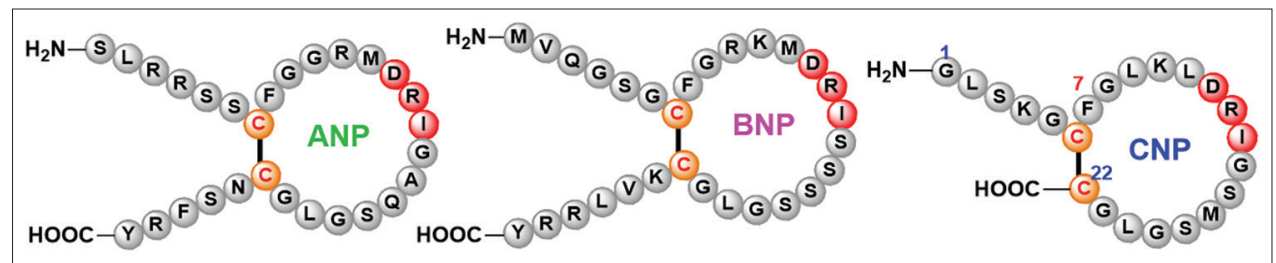

Fig. 1: Structures of mammalian natriuretic peptides

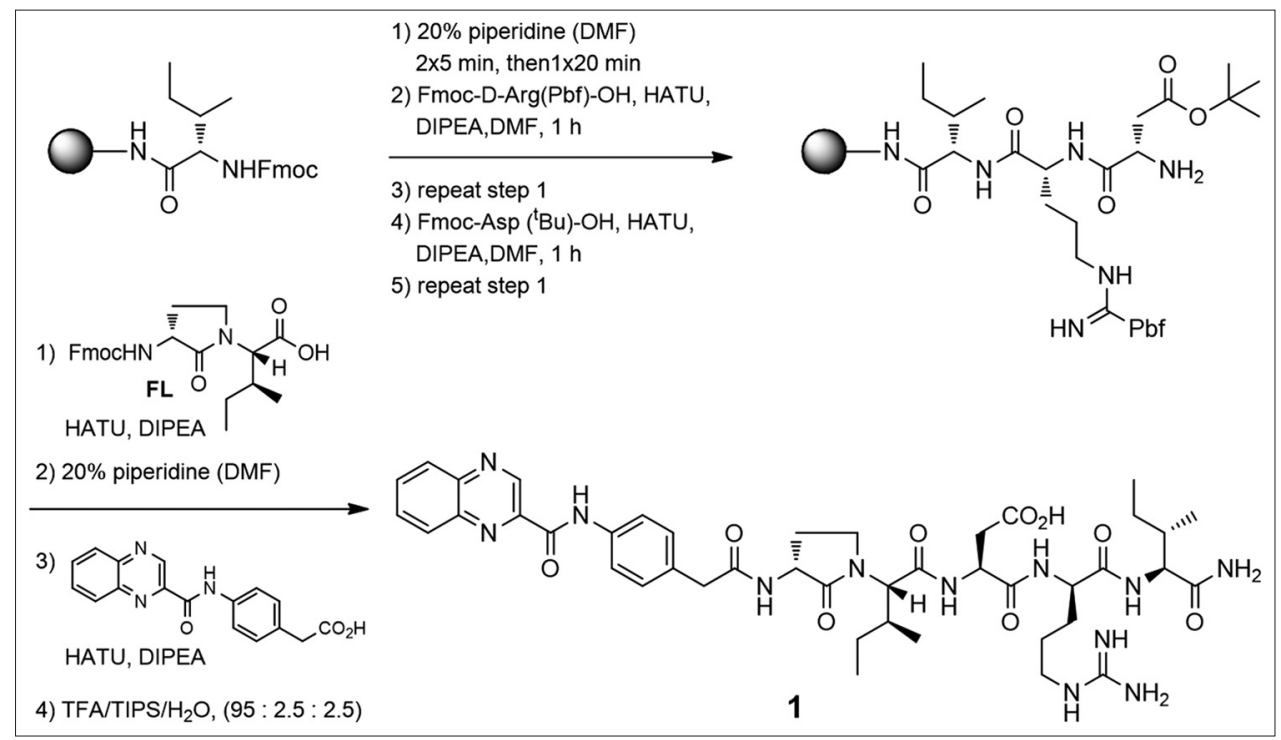

Fig. 2: Representative solid-phase peptide synthesis of natriuretic peptide clearance receptor antagonists 


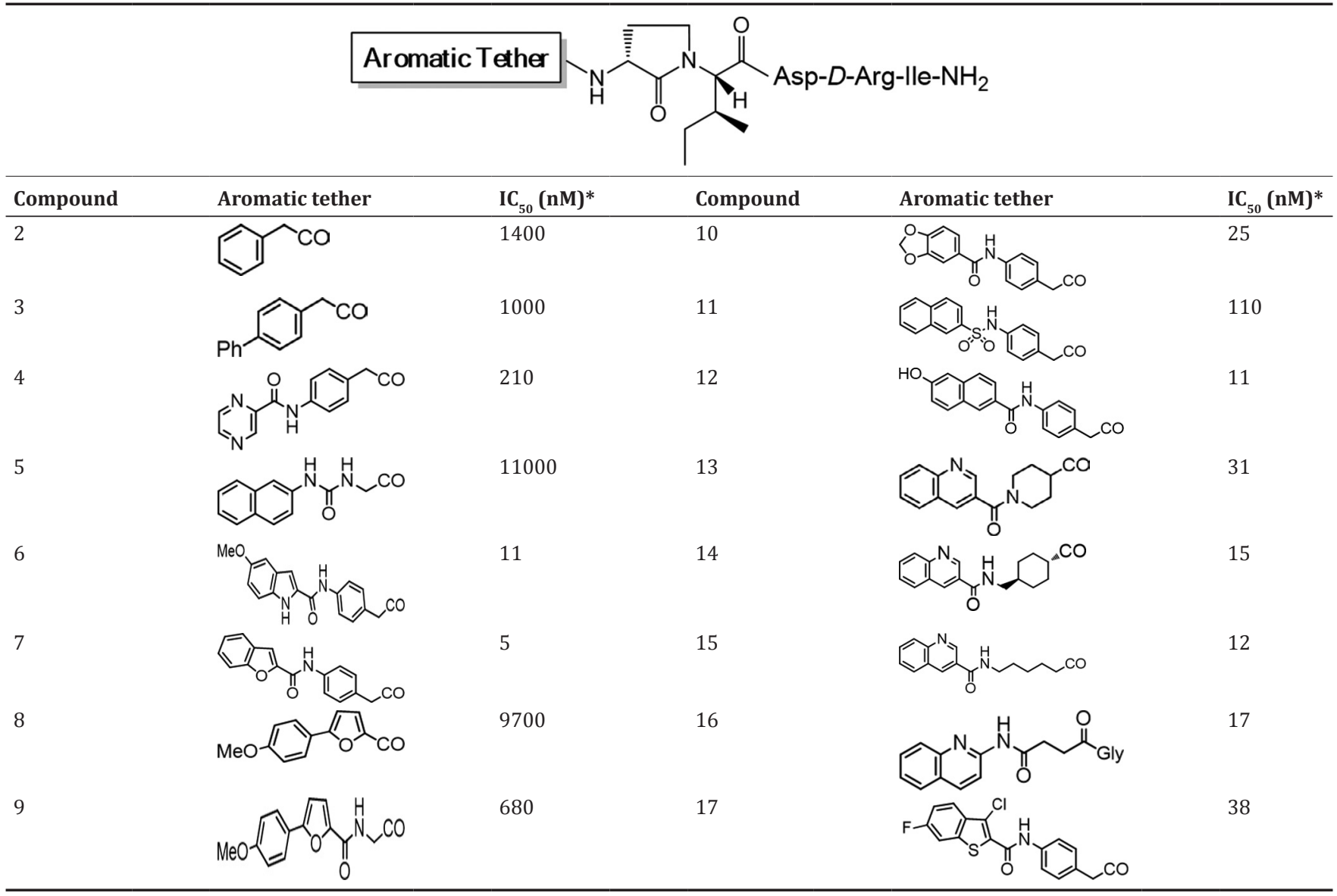

*Values are based on mean of three replicates

It seems that the length of the tether is important to dip into the Phe-7 pocket of the receptor (see CNP structure, Fig. 1). For example, compound 4 lacking the second aromatic ring is much less potent than compound 1 . A similar observation can be made when comparing compounds 8 and 9 in that the aromatic moiety must be reaching the Phe-7 pocket for better potency (compound 9). The aminophenylacetic acid moiety of compound 1 can be replaced with aminomethyl cyclohexyl carboxylic acid or with more flexible straight chain aminohexyl moieties (compounds 14 and 15, respectively). Heteroatoms within or on the aromatic nucleus also seem to contribute to potency; possibly through hydrogen bonding. Incorporating urea (compound 5) or sulfonamide (compound 11) at the quinoxaline amide position in compound 1 drastically reduced potency. The quinoxaline nucleus can successfully be replaced with indol, benzofuran, naphthyl, and benzothiophene moieties (compounds $6,7,12$, and 17 , respectively).

To access novelty in the design, we investigated the replacement of the FL moiety in compound 1 with readily available amino acids. We envisioned that Pro and its mimics may induce a similar $\beta$-turn that the FL is known to induce. Successfully, this replacement led to equally potent compounds. These binding results, as well as stability studies on these compounds, will be communicated in future publications.

\section{CONCLUSION}

NPR-C antagonists with low nanomolar potency were rapidly prepared by SPPS that is amenable to scale-up. SAR studies indicated the right aromaticity nucleus needed at the Phe-7 pocket of the receptor. Once the PK properties are established, the potential application of some of these compounds in treating achondroplasia will be investigated.

\section{ACKNOWLEDGMENT}

The author is thankful to Jubail Industrial College, Saudi Arabia, for support in preparing and writing this manuscript. The assistance of Dr. Isabelle Lemire with biological testing is greatly appreciated.

\section{REFERENCES}

1. Vasile VC, Jaffe AS. Natriuretic peptides and analytical barriers. Clin Chem 2017;63:50-8.

2. Baxter GF. The natriuretic peptides. Basic Res Cardiol 2004;99(2):71-5.

3. Rose RA, Giles WR. Natriuretic peptide C receptor signalling in the heart and vasculature. J Physiol 2008;586(2):353-66.

4. Thomas G, Moffatt P, Salois P, Gaumond MH, Gingras R, Godin E, et al. Osteocrin, a novel bone-specific secreted protein that modulates the osteoblast phenotype. J Biol Chem 2003;278(50):50563-71.

5. Yasoda A, Komatsu Y, Chusho H, Miyazawa T, Ozasa A, Miura M, et al. Overexpression of CNP in chondrocytes rescues achondroplasia through a MAPK-dependent pathway. Nat Med 2004;10(1):80-6.

6. Bartels CF, Bükülmez H, Padayatti P, Rhee DK, van RavenswaaijArts C, Pauli RM, et al. Mutations in the transmembrane natriuretic peptide receptor NPR-B impair skeletal growth and cause acromesomelic dysplasia, type Maroteaux. Am J Hum Genet 2004;75(1):27-34.

7. Amblard M, Fehrentz JA, Martinez J, Subra G. Methods and protocols of modern solid phase Peptide synthesis. Mol Biotechnol 2006;33(3):239-54.

8. Behrendt R, White P, Offer J. Advances in Fmoc solid-phase peptide synthesis. J Pept Sci 2015;22:4-27.

9. Saxena R, Manjan MJ. A thermally responsive short elastin like polypeptide-drug conjugate: Synthesis, characterization and biological evaluation for targeted delivery of anticancer drugs. Int J Pharm Pharm Sci 2014;6:326-33.

10. Anbarasi G, Kumar SK, Narmadha P, Srinivasan N. Effect of Vitamin C on mRNA expression of bmps during fracture healing in the femur callus of Sprague-Dawley female rats. Int J Pharm Pharm Sci 2014;6:208-12.

11. Freidinger RM. Synthesis of $\gamma$-lactam-constrained tryptophyllysine 
derivatives. J Org Chem 1985;50:3631-3.

12. Wolfe MS, Dutta D, Aubé J. Stereoselective synthesis of freidinger lactams Using oxaziridines derived from amino acids. J Org Chem 1997;62(3):654-63.
13. Veale CA, Alford VC, Aharony D, Banville DL, Bialecki RA, Brown FJ, et al. The discovery of non-basic atrial natriuretic peptide clearance receptor antagonists. Part 1. Bioorg Med Chem Lett 2000;10(17):1949-52. 